\title{
Judicial activism and judicial restraint at the Bundesverfassungsgericht: Was the Mangold judgement of the European Court of Justice an ultra vires act?
}

\author{
Dr. Malte Beyer-Katzenberger
}

Published online: 3 December 2010

(C) ERA 2010

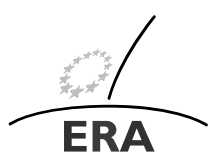

EUROPÄISCHE RECHTSAKADEMIE ACADEMY OF EUROPEAN LAW ACADEMIE DE DROIT EUROPEEN ACCADEMIA DI DIRITTO EUROPEO TRIER - TREVES - TREVIRI

The German Constitutional Court (Bundesverfassungsgericht) is undoubtedly one of the most respected and influential national courts in the European Union, notwithstanding the limits it sets to an overly pro-integration agenda. Only one year after the decision of the Bundesverfassungsgericht on the Lisbon Treaty, ${ }^{1}$ a judgement which could be criticised for being too restrictive on further integration, ${ }^{2}$ this Court appears to be trying to send a message which goes in the opposite direction.

For a wider audience, the main interest of the decision lies in the response given in it to the question of whether an activist jurisprudence of the European Court of Justice can be regarded as an ultra vires act, violating the principle of conferral. We will see that the Bundesverfassungsgericht is prepared to exercise judicial restraint with such an activist jurisprudence-under certain conditions.

Two other elements addressed in the case warrant the attention of non-German lawyers: the constitutional protection under German law of the obligation to refer questions to the European Court of Justice for a preliminary ruling under Article 267 TFEU and the question of how to address concerns of legitimate expectations once a national law has been found to violate European Union law by the European Court of Justice.

\footnotetext{
${ }^{1}$ Judgement of the Bundesverfassungsgericht (Second Senate) of 30/06/2009 in joint cases 2 BvE 2/08, 2 BvE 5/08, 2 BvR 1010/08, 2 BvR 1022/08, 2 BvR 1256/08 an 2 BvR 182/09.

${ }^{2}$ Cf. contribution by the author in ERA Forum 2009, p. 625.
}

A note on the judgement of the Bundesverfassungsgericht (Second Senate) of 06/07/2010 in constitutional complaint case 2 BvR 2661/06.

M. Beyer-Katzenberger Project Manager $(\varangle)$

Public and Criminal Law, Academy of European Law (ERA), Metzer Allee 4, 54295 Trier, Germany e-mail: mbeyer@era.int 
The concept of the ultra vires act violating the principle of conferral was first identified in the Maastricht judgement. ${ }^{3}$ In that case the Bundesverfassungsgericht declared itself competent to verify whether the principle of conferral had been respected by the European Union institutions, arguing that there could be acts of the then-Community institutions that were not covered by conferred powers and were therefore ultra vires.

The presumed ultra vires act in the case under discussion in this editorial was a particular case, namely a line of jurisprudence of the European Court of Justice, starting with the decision in the case of Mangold. ${ }^{4}$ As is well known, in this judgement the European Court of Justice found that there exists a general principle of European Union law preventing discrimination on the grounds of age. This judgement has been criticised as being the result of an activist jurisprudence of the Court. The applicants in the case before the Bundesverfassungsgericht argued that the European Court of Justice had ignored the established standards of methodology relating to the interpretation of laws. The former president of the Bundesverfassungsgericht and President of the Federal Republic of Germany, Roman Herzog, together with other scholars contributed to the debate on Mangold and other judgements of the European Court of Justice saying 'Stop the ECJ' 5 and supporting control by the national courts, such as the Bundesverfassungsgericht.

More than the substance of its findings in the Mangold case, the tone of the Bundesverfassungsgericht is interesting. The Bundesverfassungsgericht argues for judicial restraint to be exercised by itself when controlling whether an act of the Union institutions is ultra vires.

The Court affirms the autonomy and the supremacy of Union law in the way it is construed by the European Court of Justice. It affirms that these principles are covered by the constitutional provisions of the Grundgesetz.

However, only such Union law has supremacy as respects the division of competences and in particular the principle of conferral. The Court reiterates its previous jurisprudence to the effect that it feels competent to adjudicate on presumed violations of this principle insofar as these have an effect on the legal order in Germany.

However, its role as defined above, has to be exercised in 'coordination' with the European Court of Justice. ${ }^{6}$ There should be a cooperative way between the national and the Union courts to address any of the 'rare' cases of conflict over the distribution of competences. Both sides should exercise restraint. Such a call for a relationship of cooperation dates back to the Maastricht decision of 1993. The Bundesverfassungsgericht elaborates that on the one hand, the uniform application of Union law would not be possible, should every Member State claim to be competent to adjudicate on the validity of acts of Union law. On the other hand, it affirms that the Union organs cannot be solely competent to be the final arbiter on conflicts of competence cases

\footnotetext{
${ }^{3}$ Brunner case 12 October 1993, [1994] CMLR 57, the problem of shifting competences towards the European Union was identified already earlier in the Kloppenburg decision of 8 April 1987.

${ }^{4}$ Rs. C-144/04, judgement of 22 November 2005, [2005] ECR p. I-9981.

${ }^{5}$ Article published in the leading German broadsheet Frankfurter Allgemeine Zeitung on 8 September 2009.

${ }^{6}$ Para. 56 of the judgement.
} 
as the European Union has not passed the step towards a federal entity (Bundesstaat) and the member states are still to be considered 'masters of the Treaties' (the 'Herren der Verträge' doctrine). ${ }^{7}$

The innovation in this judgement is the emphasis which the Bundesverfassungsgericht placed on the point that ultra-vires control shall be exercised with restraint and in a way that respects the specific nature of Union law ('europarechtsfreundliche Anwendung'). This has several consequences. The first is an obligation to give the European Court of Justice a chance to voice its opinion in the framework of a preliminary reference procedure on the alleged violation of the principle of conferral. Secondly, in order to find an act to be ultra vires, the violation of the principle of conferral should be 'sufficiently serious'. Regarding the notion of a 'sufficiently serious breach' the Bundesverfassungsgericht refers to the European Court of Justice jurisprudence in the area of non-contractual liability of the Union. The Bundesverfassungsgericht qualifies a breach as 'sufficiently serious' when it is (1) 'manifest' ('offensichtlich') and (2) when the act in question has a serious impact on the distribution of competences between Member States and the Union.

The main point of interest in this case was the question of whether an activist jurisprudence of the European Court of Justice could constitute an ultra vires act. The Bundesverfassungsgericht emphasised that it is the role of the Court of Justice to develop the legal rules of Union law as long as it is done following the established standards of methodology relating to the judicial interpretation of laws ('Rechtsfortbildung im Rahmen methodisch gebundener Rechtssprechung'). Already in its 1987 decision, the Bundesverfassungsgericht had written that "judges in Europe never have been only "la bouche qui prononce les paroles de la loi"; Roman law, English common law and [Germanic] common law ['das Gemeine Recht'] were mainly judgemade law as well as were more recent innovations of general principles of administrative law in France and Germany, many parts of labour law and the law of securities in private law relations. [... ] It would be misleading to deny the Court of Justice of the Communities to develop the law further by way of judicial interpretation."

According to the judgement, rules are open for judicial interpretation when they leave room for different ways of implementation, contain gaps that were not intended to be there or when there is a conflict between two legal norms that needs to be resolved. However, there are limits for courts when they develop the law based on judicial interpretation. Courts are bound by the text of legislative provisions, may not change the clear intentions of the legislator and may not create legal rules that have no basis in legislative provisions. In no event may the European Court of Justice set its own political programme or alter fundamentally the division of competences between the Union and the Member States as the principle of conferral is one of the fundamental rules of Union law.

In a situation where a legal rule can be construed differently or a situation assessed differently, the Bundesverfassungsgericht clarified in the present case that it can not

\footnotetext{
${ }^{7}$ This view is criticised by EU-integration friendly scholars, such as J. Schwarze, Kommentierung zu Artikel 220 EGV, Rn. 24, in: J. Schwarze (Ed.), 2nd ed. 2009, Baden-Baden: Nomos.

${ }^{8}$ Bundesverfassungsgericht, decision of 8 April 1987 [Kloppenburg], §48; the French words quoted were used in the original version.
} 
claim the right to substitute an interpretation of Union law by the European Court of Justice that complies with the accepted standards of legal methodology with its own interpretation. Beyond this, the Bundesverfassungsgericht needs also to accept isolated cases of the interpretation of the Treaties that may not be in line with such accepted standards as long as these cases do not fundamentally alter the division of competences and if there is no impact on the fundamental rights of individuals.

The Bundesverfassungsgericht does not decide in its ruling whether the solution found by the European Court of Justice in Mangold is still in line with accepted standards of legal methodology. In any event, it argues that such a jurisprudence does not fundamentally alter the division of competences. Therefore the Bundesverfassungsgericht accepts the need to exercise restraint in light of the specific nature of Union law as supranational law.

Concretely, the Court examines in the ruling the issue of whether the division of competences has been respected under three headings:

First, it addresses the argument that the situation in Mangold fell outside the scope of Union law as it was a matter of employment policy, an exclusive competence of the Member States. Consequently, it had been argued, the European Court of Justice had no role to play in this particular dispute.

The Bundesverfassungsgericht accepts the approach of the European Court of Justice finding that the situation of Mangold was regulated by legislation transposing a European Union Directive (in this case Directive 2000/78/EC). In situations where European Union Directives are applicable, such situations fall within the scope of application of the Treaties. It could be argued that the national legislator intended to pass the relevant statutory provision mainly to achieve other objectives unrelated to the Directive. According to the Bundesverfassungsgericht, however, the national legislator has no discretion to define objectives in such a way to limit the scope of application of Union law when there are clear obligations flowing from European Union Directives.

Secondly the Bundesverfassungsgericht addresses the question of whether the European Court of Justice did fundamentally alter the division of competences in limiting the discretion of the German legislator already before the date of transposition for the Directive 2000/78/EC had passed. The Bundesverfassungsgericht refers to earlier jurisprudence of the European Court of Justice arguing that Member States had to refrain from any action that might frustrate the objectives of a Directive already before the date of transposition. ${ }^{9}$ The Mangold ruling of the European Court of Justice went beyond this in creating stronger obligations on member states not to frustrate such objectives. The Bundesverfassungsgericht accepted the ECJ's view that this was due to the specific nature of the case: Germany asked for an extended deadline for transposition. This was permissible under Article 18 of the Directive. Article 18 did, however, put an obligation on a Member State using this exception to provide annual reports on how it was improving the situation in the area of discrimination on the grounds of age.

Thirdly, the Bundesverfassungsgericht discusses the argument that the European Court of Justice has 'invented' a general principle of European Union on age discrimination. While the Bundesverfassungsgericht voices some doubts as to the soundness

${ }^{9}$ Case C-129/96 Inter-Environment Wallonie, judgement of 18 December 1997, [1997] ECR, p. I-7411. 
of the argument that such a principle exists, it underlines that such an activist jurisprudence would only be a problem if it created new competences for the Union and obligations for individuals. The Bundesverfassungsgericht rejects the argument that the European Court of Justice created new competences of the Union. It notes that it was the member states' representatives in Council (including the German representative) who were extending the competences of the Union when passing legislation based on Article 19(1) TFEU prohibiting age discrimination in employment situations.

In the second part of its judgement the Bundesverfassungsgericht clarifies the extent of its control on the obligation to refer a question to the European Court of Justice for a preliminary ruling under the constitutional provisions of Germany. Under German constitutional law, everyone has the constitutional right for his case to be heard by a judge. The Bundesverfassungsgericht has interpreted this provision to include the right to have a question referred to the European Court of Justice for a preliminary ruling. The Bundesverfassungsgericht therefore is competent to supervise the application of this constitutional right. However, its supervisory role is limited to clearly arbitrary violations. Union law does not oblige the Bundesverfassungsgericht to fully control the respect for Article 267 TFEU by German courts. Leaving aside clear-cut cases where the national court ignores the obligation to refer a question for preliminary ruling altogether, the Bundesverfassungsgericht examines the case where there exists no clear jurisprudence of the European Court of Justice. Here the national courts are not constitutionally obliged to refer a question where they follow one of several possible interpretations in their judgement. Only when a national court follows an interpretation of European Union law that can be advanced but is manifestly not convincing, is it constitutionally bound to refer the question to the European Court of Justice.

Finally, the Bundesverfassungsgericht elaborates on the protection of legitimate expectations in the light of a changing jurisprudence of the European Court of Justice and the responses to questions referred for a preliminary ruling. The Bundesverfassungsgericht accepts that preliminary rulings of the European Court of Justice have a retroactive (ex tunc) effect. National law incompatible with Union needs to be set aside not only as of the day of the preliminary ruling, but from the day the conflicting Union law existed. Individuals cannot rely on legitimate expectations as to the lawfulness of their relations. It is only for the European Court of Justice to limit the effect of its preliminary rulings in time. National courts in Germany may award compensation in order to take account of the constitutional protection of legitimate expectations under German law. This was however not relevant for the case at hand.

In conclusion we can say that the Bundesverfassungsgericht refines its jurisprudence on ultra vires acts. It had its first opportunity to respond to criticism directed towards an important recent European Court of Justice case. The Court has used a strictly legal approach to address the criticism that the European Court of Justice's jurisprudence has been too activist in the past. It does not seek outright conflict on the substance on some of the cases that were criticised by scholars for being the outcome of an activist invention of new general principles of EU law, such as in the Mangold case. On the contrary, it pays tribute to the recognised principles of European Union law such as autonomy and supremacy, and to the monopoly which the European Court of Justice should enjoy when interpreting European Union law. It accepts 
that there may be diverging opinions on the extent to which Union law can and should be further developed by way of judicial interpretation. It reminds the European Court of Justice of certain standards for interpreting and developing Union law further by way of judicial interpretation. However, decisions that are incompatible with those standards will not be regarded as ultra vires acts if they have no impact on the distribution of competences between the Union and the Member States. This represents a relatively generous gesture towards the European Court of Justice.

A certain link can be made with the famous Solange jurisprudence of the Bundesverfassungsgericht. The Court there claimed in principle the right to monitor the respect of the fundamental rights of German citizens by European Union institutions. However, it also established that there is a presumption that the European Court of Justice ensures an equivalent human rights standard in general, leaving a high burden on the individual to prove the absence of adherence to such a general standard.

For the situation of the violation of the principle of conferral and the ultra vires acts, the Bundesverfassungsgericht stops short of such a presumption, but it has raised standards with the present judgement. From now on an applicant before the Constitutional Court in Germany has not only to demonstrate that a specific act is not covered by the principle of conferral, but also that this act has an impact on the general division of competences between the EU and the Member States, something very difficult to argue. It is even more difficult to argue, because the shifting of power to the European Union through the jurisprudence of the European Court of Justice is likely to happen incrementally, given the very nature of court decisions. They will always address individual cases and can only very theoretically lead to a fundamental shift in the distribution of powers. ${ }^{10}$

Unfortunately the Bundesverfassungsgericht could not address the question of whether it had been the Council which had shifted the division of competences when it adopted the Directives that were at issue, expanding the Union competence in the field of employment law. It will be interesting to see cases in the future where it is not the Court, but the Union legislator which is accused of infringing the principle of conferral.

What remains unclear is the relationship between the two elements that make up the new integration-friendly approach in the application of the ultra vires control, i.e. the obligation to refer a question on respect with the principle of conferral to the European Court of Justice for preliminary ruling and, secondly, the introduction of a new threshold, meaning that only 'sufficiently serious' breaches of the principle of conferral could trigger the control by the Bundesverfassungsgericht. In principle, in order to comply with the role given to the European Court of Justice by the Treaties to be the sole arbiter on European Union law related disputes and also with the relationship of cooperation proclaimed by the Bundesverfassungsgericht, the national court would have to always first refer the question to the European Court of Justice before addressing itself to the question of whether the breach was sufficiently serious.

\footnotetext{
${ }^{10}$ This argument has been brought forward by former Bundesverfassungsgericht judge Dieter Grimm who was involved in the Maastricht decision in a contribution to the broadsheet Frankfurter Allgemeine Zeitung of 9 September 2010; according to his argument fundamental shifts are the result of cumulative decisions in individual cases.
} 
The Bundesverfassungsgericht once more finds it unnecessary to take the opportunity of the present case to refer a question. It examines directly whether the alleged breach was sufficiently serious. It thus missed the chance to live up to the standards it proclaims in terms of cooperating with the European Court of Justice. 